\title{
Duration of weaning, starter intake, and weight gain of dairy calves fed large amounts of milk
}

\author{
B. C. Sweeney, ${ }^{*}$ J. Rushen, ${ }^{*}$ D. M. Weary, † and A. M. de Passillé ${ }^{* 1}$ \\ ${ }^{*}$ Pacific Agri-Food Research Centre, Agriculture and Agri-Food Canada, Agassiz, British Columbia, Canada \\ †Animal Welfare Program, University of British Columbia, Vancouver, British Columbia, Canada
}

\begin{abstract}
When calves are weaned abruptly off large amounts of milk, weight gain is reduced as a result of low intake of starter. We compared gradual and abrupt weaning of 40 calves allowed to drink up to $12 \mathrm{~kg}$ of milk/d by automated feeders, housed in groups of 4 , and weaned at $41 \mathrm{~d}$ abruptly or over 3 gradual weaning periods (4, 10 , or $22 \mathrm{~d}$ ), with one calf within each group randomly allocated to each treatment, balancing for sex and birth weight. During the milk-feeding period, the calves weaned over $22 \mathrm{~d}$ drank the least milk and ate the most starter, but these calves had the lowest total digestible energy intake and weight gains. The abruptly weaned calves had the highest digestible energy intakes and weight gains during the period before weaning. During the $9 \mathrm{~d}$ following weaning, the calves weaned over 22 and $10 \mathrm{~d}$ ate more starter and had better weight gains than abruptly weaned calves and those weaned over $4 \mathrm{~d}$. Abruptly weaned calves lost weight during this period. In summary, gradual weaning improved starter intake, but because of reduced milk availability, this resulted in reduced total digestible energy intake before weaning. Weaning over $10 \mathrm{~d}$ resulted in the best overall weight gains over the study.
\end{abstract}

Key words: dairy calf, gradual weaning, weight gain, welfare

\section{INTRODUCTION}

Dairy calves in North America are typically fed milk at 8 to $10 \%$ of $\mathrm{BW} / \mathrm{d}$ or equivalent amounts of milk replacer. In contrast, dairy calves allowed to suckle from cows (Flower and Weary, 2001; de Passillé et al., 2008) or allowed ad libitum access to milk (Jasper and Weary, 2002; Borderas et al., 2009) drink considerably larger volumes $(8-12 \mathrm{~L} / \mathrm{d})$ of milk and grow at roughly twice the rate. Increasing the amount of milk or milk replacer fed to calves improves growth rates (Huuskonen and Khalili, 2008), feed efficiency (Diaz et al., 2001),

Received May 27, 2009.

Accepted September 20, 2009.

${ }^{1}$ Corresponding author: Annemarie.Depassille@agr.gc.ca and the efficiency of automated milk feeding systems (Jensen, 2006; De Paula Vieira et al., 2008; Borderas et al., 2009), and possibly improves later milk production (Drackley et al., 2007), with no negative effects on calf health (Khan et al., 2007; Borderas et al., 2009) or mammary gland development (Daniels et al., 2009).

However, feeding calves larger amounts of milk can reduce starter intake during the milk-feeding period (Terré et al., 2007; Huuskonen and Khalili, 2008), and this in turn may lead to weight loss when calves are weaned from milk (Terré et al., 2007; Budzynska and Weary, 2008; Jasper et al., 2008), reducing some of the growth advantages of larger milk rations (Huuskonen and Khalili, 2008). Abrupt weaning can lead to increased cross-sucking and signs of hunger (Nielsen et al., 2008). Gradual weaning from milk can increase calf starter consumption and reduce the growth check (Khan et al., 2007), but there is little knowledge about the effect of different durations of gradual weaning on starter intake and weight gains of calves fed large amounts of milk.

The aim of this study was to examine the effects of gradual weaning periods on the intake of calf starter and weight gain during and immediately after weaning of calves fed large amounts of milk.

\section{MATERIALS AND METHODS}

This study was conducted at the University of British Columbia Dairy Education Center (Agassiz, British Columbia, Canada). All experimental conditions and procedures were approved by the Institutional Animal Care Committee, which met the requirements of the Canadian Council for Animal Care (2009).

\section{Housing and Management}

At 4 to $7 \mathrm{~d}$ of age, 24 female and 16 male Holstein calves were housed in groups of 4 in $4.87-\times 7.31-\mathrm{m}$ wood shavings-bedded pens with a partially slatted floor. Calves were fed pasteurized nonsaleable milk (herd average of $3.97 \%$ fat, $4.10 \%$ protein, $3.30 \%$ lactose based on bulk tank samples) at $40^{\circ} \mathrm{C}$. Calves had ad libitum access to a textured calf starter $(17.9 \% \mathrm{CP}$ 
Table 1. Descriptions of the 4 weaning treatments ${ }^{1}$

\begin{tabular}{lccc}
\hline Treatment & $\begin{array}{c}\text { Age when weaning } \\
\text { began }(\mathrm{d})\end{array}$ & $\begin{array}{c}\text { Duration of weaning } \\
\text { period }(\mathrm{d})\end{array}$ & $\begin{array}{c}\text { Average daily reduction } \\
\text { in milk allowed }(\mathrm{kg} / \mathrm{d})\end{array}$ \\
\hline 22-d weaning & 19 & 22 & 0.55 \\
10-d weaning & 31 & 10 & 1.20 \\
4-d weaning & 37 & 4 & 3.00 \\
Abrupt weaning & 41 & 1 & 12.00 \\
\hline
\end{tabular}

${ }^{1}$ Before weaning, all calves were allowed to drink up to $12 \mathrm{~kg} / \mathrm{d}$ of milk.

on a DM basis, with the main ingredients being $16 \%$ wheat, $14 \%$ barley, $13 \%$ canola meal, $13 \%$ oats, $10 \%$ soy, $10 \%$ corn, and $4 \%$ molasses; Unifeed Ltd., Chilliwack, Canada) from automated feeders supplying milk and starter, with both feeders controlled by a single computer (CF 1000 CS Combi, DeLaval Inc., Tumba, Sweden). This computer recognized individual calves from their radio frequency ID (RFID) tags and could control and record both milk and starter intake independently for each calf. Starter and water were available ad libitum. From the first day they were placed in group pens, calves were allowed to drink up to $12 \mathrm{~kg} / \mathrm{d}$ of milk. Weigh scales (Smart1, Westernscale Inc., Port Coquitlam, British Columbia, Canada) were fitted at the water trough and milk feeder, providing estimates of BW at each visit.

Fresh bedding was added to each group pen once per week. Milk feeders were automatically cleaned every day at 0700 and $1500 \mathrm{~h}$ and manually cleaned every other day at $0800 \mathrm{~h}$.

Before the experiment, the calves had been separated from their dams within $24 \mathrm{~h}$ of birth, were bottle-fed 4 $\mathrm{L}$ of colostrum containing $\geq 55 \mathrm{~g}$ of $\mathrm{Ig} / \mathrm{L}$ within $6 \mathrm{~h}$ after birth, weighed, and moved into individual sawdustbedded pens $(1.22 \times 2.44 \mathrm{~m})$. While in individual pens, the calves were bottle fed $3 \mathrm{~L}$ of whole milk at 0800 and $1530 \mathrm{~h}$ (consuming $5.17 \pm 1.03 \mathrm{~L} / \mathrm{d}$ ) and had ad libitum access to water in buckets.

\section{Experimental Treatments}

Calves were assigned to 1 of 4 weaning treatments (Table 1), balancing for weight, sex, and age. Each pen contained one calf from each treatment. Weaning was completed at $41 \mathrm{~d}$ of age for all calves.

\section{Data Analysis}

The quantities of milk and starter consumed by each calf at each visit were automatically recorded and converted to daily milk and starter intakes. We estimated daily digestible energy (DE) intake for each individual calf. Four samples of calf starter were analyzed (Bodycote Testing Group Inc., Lethbridge, Alberta, Canada), and DE content calculated from the analyzed chemical constituents was $3.48 \mathrm{Mcal} / \mathrm{kg}$ of DM. Milk was estimated to contain $5.59 \mathrm{Mcal} / \mathrm{kg}$ of DM (NRC, 2001). Median BW were calculated each day from recordings from the weigh scales at the milk and water feeders. The study was divided in 3 periods: the $5 \mathrm{~d}$ before any calves started the weaning process (the preweaning period), d 14 to d 18; the gradual weaning period, d 19 to d 40; and the postweaning period, d 41 to $\mathrm{d} 49$. The PROC GLM of SAS (SAS Institute Inc., Cary, NC) was used to test the effect of treatment, sex of calf, and interaction between sex and treatment separately for each period.

\section{RESULTS}

During the 5-d preweaning period (d 14 to 18 of age), milk intake, starter intake, estimated total DE intake, and weight gain averaged $( \pm \mathrm{SD}) 9.3 \pm 1.80 \mathrm{~kg} / \mathrm{d}, 0.0$ $\pm 0.01 \mathrm{~kg} / \mathrm{d}, 6.3 \pm 1.22 \mathrm{Mcal} / \mathrm{d}$, and $0.9 \pm 0.56 \mathrm{~kg} / \mathrm{d}$, respectively, with no differences between treatment groups for any measure $(P>0.10)$.

During the period of gradual weaning, milk intake declined as expected following the scheduled reductions in milk allowance (Figure 1A). Total milk intake during the gradual weaning period was lowest for the $22-\mathrm{d}$ weaning, intermediate for the 10-d and 4-d groups, and highest for the abruptly weaned calves (Table 2; $P<$ 0.001). Starter intakes before $31 \mathrm{~d}$ of age were very low (Figure 1B) and remained low for the abruptly weaned and 4-d treatments until weaning was completed. Starter intakes for the 22-d and 10-d groups started increasing after $\mathrm{d}$ 31. During the weaning period, calves weaned over $22 \mathrm{~d}$ and over $10 \mathrm{~d}$ had higher starter intakes than those in the other 2 treatment groups. However, this increased intake was not sufficient to compensate for the reduced intake of milk, with the result that total DE during weaning was lowest for the 22-d group, highest for the abruptly weaned calves, with the 10-d and 4-d treatment groups having intermediate total DE intakes (Figure 1C). The lower DE intakes before weaning translated into lesser BW gains during weaning (Figure $1 \mathrm{D})$; these gains were lowest for the calves on the $22-\mathrm{d}$ gradual weaning and highest for the abruptly weaned calves. 

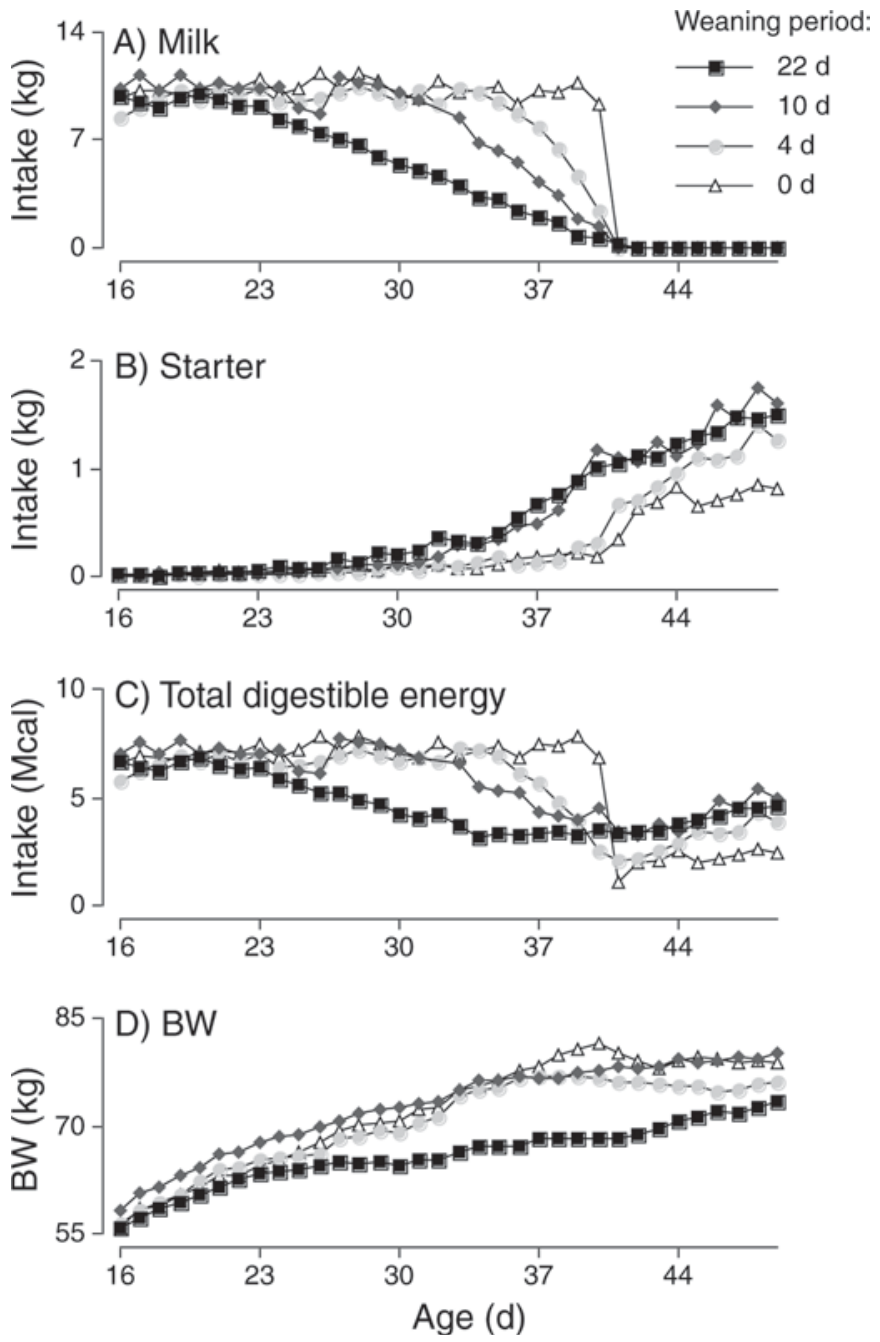

Figure 1. Mean daily intake of milk (A), calf starter (B), and estimated digestible energy $(\mathrm{C})$, and mean BW (D) for calves between d 16 and d 49 of age. Results are shown separately for calves weaned over $22 \mathrm{~d}$ (milk reduction starting on d 19 of age), $10 \mathrm{~d}$ (milk reduction starting on $\mathrm{d} 31$ ), $4 \mathrm{~d}$ (milk reduction starting on $\mathrm{d} 37$ ), and $0 \mathrm{~d}$ (abrupt weaning on d 41). Calves received no milk from d 41 onward.

Calves in all 4 treatments increased starter intake once weaning was complete (d 41), but intakes were highest in the 10-d and 22-d weaning treatments and lowest in the abruptly weaned calves (Table 2). The higher intakes, by definition, improved DE intakes, as starter was now the only source of energy available. Calves in all treatments had a lower DE intake after weaning compared with during the weaning period, showing that the increases in starter intake were not sufficient to compensate for the lost milk. Calves in the 22-d weaning group showed the smallest reduction in total DE intake once weaning was complete, in part because milk intakes were already very low at the end of the weaning period. The lower DE intake led to reduced growth rates, especially for abruptly weaned calves (which lost weight) and those in the 4-d treatment. Postweaning weight gains were equal in the 22-d and 10-d weaned calves. At d 49, the calves weaned over $10 \mathrm{~d}$ and the abruptly weaned calves were heavier than the calves of the other 2 weaning treatments.

During weaning, there were no effects of sex or interactions between sex and weaning duration on milk intake or DE intake $(P>0.10)$. After weaning, there was an effect of sex $(P=0.003)$, with male calves consuming more starter than female calves $(0.25 \pm 0.03$ vs. 0.16 $\pm 0.01 \mathrm{~kg} / \mathrm{d})$. There was also a sex by weaning duration interaction $(P=0.02)$, but the relative ranking of the different weaning durations was the same for males and females. There was no effect of sex or interaction between sex and weaning duration on weight gain $(P$ $<0.10)$

\section{DISCUSSION}

Regardless of the duration of the weaning period, the reduction in milk intake associated with gradual weaning decreased total DE intake, showing that calves did not consume sufficient starter to compensate for the loss of energy from the milk. The postweaning period is known to be associated with behavioral signs of hunger and distress and is a stressful period for calves (Weary et al., 2008). Our results are consistent with previous studies showing that calves drink large quantities of milk when it is available (Jasper and Weary, 2002; De Paula Vieira et al., 2008; Borderas et al., 2009). During the 5-d preweaning period, calves drank an average of $9 \mathrm{~kg} / \mathrm{d}$ and consumed little starter; weight gains averaged $1 \mathrm{~kg} / \mathrm{d}$. The abruptly weaned calves continued to gain weight at this rate until milk was no longer available, but these calves lost weight during the $3 \mathrm{~d}$ after weaning. Some of the immediate weight loss may reflect emptying of the gastrointestinal tract rather than loss of body tissue itself, but this seems unlikely to account for the entire amount of weight lost over the 3-d period.

Gradual weaning increased starter intakes during the weaning period and prevented the weight loss that occurred in the abruptly weaned calves. Our results suggest that weaning over $10 \mathrm{~d}$ allowed for the best overall results in terms of weight gains during and immediately after weaning. The calves weaned over 22 $\mathrm{d}$ did not show any weight loss during the $8 \mathrm{~d}$ after weaning was complete, but showed poor weight gain during the lengthy weaning period. During the weaning period, these calves were not able to compensate for the reduced milk through increased intake of calf starter, and thus experienced low total DE intakes and a long period of low growth. Weaning over $4 \mathrm{~d}$ resulted in reduced weight gain during the weaning period com- 
Table 2. Daily least squares means $( \pm \mathrm{SE})$ for milk intake, starter intake, estimated digestible energy (DE) intake, BW gains, and BW at the end of the period for calves on each weaning treatment, shown separately for the weaning and postweaning periods

\begin{tabular}{|c|c|c|c|c|}
\hline \multirow[b]{2}{*}{ Item } & \multicolumn{4}{|c|}{ Weaning treatment ${ }^{1}$} \\
\hline & Abrupt & $4 \mathrm{~d}$ & $10 \mathrm{~d}$ & $22 \mathrm{~d}$ \\
\hline Daily starter intake (kg) & $0.1 \pm 0.03^{\mathrm{a}}$ & $0.1 \pm 0.03^{\mathrm{a}}$ & $0.3 \pm 0.03^{\mathrm{b}}$ & $0.3 \pm 0.03^{\mathrm{b}}$ \\
\hline Daily DE intake (Mcal) & $7.2 \pm 0.21^{\mathrm{a}}$ & $6.1 \pm 0.24^{\mathrm{b}}$ & $6.7 \pm 0.24^{\mathrm{ab}}$ & $4.8 \pm 0.21^{\mathrm{c}}$ \\
\hline Daily BW gain $(\mathrm{kg})$ & $1.06 \pm 0.07^{\mathrm{a}}$ & $0.75 \pm 0.08^{b}$ & $0.83 \pm 0.08^{\mathrm{b}}$ & $0.50 \pm 0.07^{\mathrm{c}}$ \\
\hline Daily starter intake $(\mathrm{kg})$ & $0.7 \pm 0.09^{\mathrm{a}}$ & $1.0 \pm 0.11^{\mathrm{ab}}$ & $1.2 \pm 0.11^{\mathrm{b}}$ & $1.2 \pm 0.09^{\mathrm{b}}$ \\
\hline Daily DE intake (Mcal) & $2.1 \pm 0.29$ & $2.9 \pm 0.33$ & $3.8 \pm 0.33$ & $3.8 \pm 0.24$ \\
\hline Daily BW gain $(\mathrm{kg})$ & $-0.21 \pm 0.11^{\mathrm{a}}$ & $0.10 \pm 0.13^{\mathrm{ab}}$ & $0.23 \pm 0.13^{\mathrm{bc}}$ & $0.51 \pm 0.11^{\mathrm{c}}$ \\
\hline BW at d $49(\mathrm{~kg})$ & $80.2 \pm 2.03^{\mathrm{a}}$ & $73.2 \pm 2.30^{\mathrm{b}}$ & $82.9 \pm 2.30^{\mathrm{a}}$ & $72.2 \pm 2.02^{\mathrm{b}}$ \\
\hline
\end{tabular}

${ }^{\mathrm{a}-\mathrm{c}}$ Means with different superscripts within rows differ $(P<0.05)$.

${ }^{1}$ Treatments: Abrupt $=$ abruptly weaned at $41 \mathrm{~d}$ of age; $4 \mathrm{~d}=$ weaned over $4 \mathrm{~d}$ beginning at $37 \mathrm{~d}$ of age; $10 \mathrm{~d}=$ weaned over $10 \mathrm{~d}$ beginning at $31 \mathrm{~d}$ of age; $22 \mathrm{~d}$ = weaned over $22 \mathrm{~d}$ beginning at $19 \mathrm{~d}$ of age.

pared with the abruptly weaned group, but did not significantly improve weight gain after weaning because the weaning period was too short to stimulate increased starter intake. Because starter intake after weaning varies in relation to the starter eaten during the period of gradual weaning, some combination of gradual weaning (to stimulate starter intake) and reducing milk intake on the basis of starter intake (Roth et al., 2009) may be the best way of weaning calves fed large amounts of milk.

Weaning age is also likely to be important. In the current study, with weaning at 6 wk of age, calves in the 4-d and 10-d weaning treatment groups appeared to be able to increase starter intake faster than the 22 -d group, perhaps because the 22-d group began the weaning process at only $19 \mathrm{~d}$ of age. The 22 -d treatment might have been more successful if it had begun at a later age.

\section{CONCLUSIONS}

Gradually reducing milk availability before weaning improved the consumption of starter. However, calves were unable to fully compensate for the reduced milk availability and showed poorer gains before weaning, especially when gradual weaning was begun at $19 \mathrm{~d}$ of age. For calves in the current study, fed large amounts of milk and weaned at 6 wk of age, gradually reducing the milk allowance over a 10-d period resulted in the best overall weight gains.

\section{ACKNOWLEDGMENTS}

We thank Nelson Dinn and the staff of the University of British Columbia Dairy Education and Research
Centre, in particular Fernando Borderas, Rachel Drennan, Jason Hershman, Mairi Robertson, Kate Kjelsrud, Benjamin Reid, and Nina von Keyserlingk, for their help. The project was funded by an NSERC Discovery grant and by Agriculture and Agri-Food Canada (Agassiz, British Columbia, Canada). The research reported here forms part of the MSc thesis of B. C. Sweeney at the University of Edinburgh (Edinburgh, UK).

\section{REFERENCES}

Borderas, T. F., A. M. de Passillé, and J. Rushen. 2009. Feeding behavior of calves fed small or large amounts of milk. J. Dairy Sci. $92: 2843-2852$.

Budzynska, M., and D. M. Weary. 2008. Weaning distress in dairy calves: Effects of alternative weaning procedures. Appl. Anim. Behav. Sci. 112:33-39.

Canadian Council for Animal Care. 2009. The Care and Use of Farm Animals in Research, Teaching and Testing. Canadian Council for Animal Care, Ottawa, Ontario, Canada.

Daniels, K. M., M. L. McGilliard, M. J. Meyer, M. E. Van Amburgh, A. V. Capuco, and R. M. Akers. 2009. Effects of body weight and nutrition on histological mammary development in Holstein heifers. J. Dairy Sci. 92:499-505.

de Passillé, A. M., P. G. Marnet, H. Lapierre, and J. Rushen. 2008. Effects of twice-daily nursing on milk ejection and milk yield during nursing and milking in dairy cows. J. Dairy Sci. 91:1416-1422.

De Paula Vieira, A., V. Guesdon, A. M. de Passillé, M. A. G. von Keyserlingk, and D. M. Weary. 2008. Behavioural indicators of hunger in dairy calves. Appl. Anim. Behav. Sci. 109:180-189.

Diaz, M. C., M. E. Van Amburgh, J. M. Smith, J. M. Kelsey, and E. L. Hutten. 2001. Composition of growth of Holstein calves fed milk replacer from birth to 105-kilogram body weight. J. Dairy Sci. 84:830-842.

Drackley, J. K., B. C. Pollard, H. M. Dann, and J. A. Stamey. 2007. First-lactation milk production for cows fed control or intensified milk replacer programs as calves. J. Dairy Sci. 90(Suppl. 1):779.

Flower, F. C., and D. M. Weary. 2001. Effects of early separation on the dairy cow and calf: 2 . Separation at 1 day and 2 weeks after birth. Appl. Anim. Behav. Sci. 70:275-284.

Huuskonen, A., and H. Khalili. 2008. Computer-controlled milk replacer feeding strategies for group-reared dairy calves. Livest. Sci. 113:302-306 
Jasper, J., M. Budzynska, and D. M. Weary. 2008. Weaning distress in dairy calves: Acute behavioural responses by limit-fed calves. Appl. Anim. Behav. Sci. 110:136-143.

Jasper, J., and D. M. Weary. 2002. Effects of ad libitum milk intake on dairy calves. J. Dairy Sci. 85:3054-3058.

Jensen, M. B. 2006. Computer-controlled milk feeding of group-housed calves: The effect of milk allowance and weaning type. J. Dairy Sci. 89:201-206.

Khan, M. A., H. J. Lee, W. S. Lee, S. B. Kim, K. S. Ki, J. K. Ha, H G. Lee, and Y. J. Choi. 2007. Pre- and postweaning performance of Holstein female calves fed milk through step-down and conventional methods. J. Dairy Sci. 90:876-885.

NRC. 2001. Nutrient Requirements of Dairy Cattle. 7th rev. ed. National Academy Press, Washington, DC.
Nielsen, P. P., M. B. Jensen, and L. Lidfors. 2008. Milk allowance and weaning method affect the use of a computer controlled milk feeder and the development of cross-sucking in dairy calves. Appl. Anim. Behav. Sci. 109:223-237.

Roth, B. A., N. M. Keil, L. Gygax, and E. Hillmann. 2009. Influence of weaning method on health status and rumen development in dairy calves. J. Dairy Sci. 92:645-656.

Terré, M., M. Devant, and A. Bach. 2007. Effect of level of milk replacer fed to Holstein calves on performance during the preweaning period and starter digestibility at weaning. Livest. Sci. 110:82-88.

Weary, D. M., J. Jasper, and M. J. Hötzel. 2008. Understanding weaning distress. Appl. Anim. Behav. Sci. 110:24-41. 